\title{
Female Leadership Talent Development: The Brazilian Context
}

\author{
El desarrollo de talento para el liderazgo femenino: el contexto brasileño \\ 0 Desenuolvimento do Talento de Liderança Feminina: 0 Contexto Brasileiro
}

\author{
Renata Muniz Prado* \\ Denise de Souza Fleith* \\ University of Brasilia, Brasilia, Brazil.
}

Doi: http://dx.doi.org/10.12804/revistas.urosario.edu.co/apl/a.4619

\section{Abstract}

Women's participation in leadership positions is increasing all over the world. Nevertheless, an analysis of the top positions of several careers shows that this progress has been insufficient to equitably drive the professional rise of women to the highest levels of responsibility, power and prestige. In Brazil the situation is not different. Various factors contribute to this phenomenon. Social and cultural influences play a particularly important role in the development of female leadership talent, impacting not just the behavioral patterns incorporated and displayed by women, but also the structure of their professional fields. Hence, this study aimed to analyze the development of talent in the light of gender studies, with an emphasis on factors that interfere in the rise of Brazilian women towards positions of power and leadership. This approach is hoped to elicit a reflection on how the unequal conditions experienced by women are perpetuated and often made to seem natural by valuing their "difference".

Keywords: leadership, gender, talent, brazilian women, female underrepresentation.

\section{Resumen}

La creciente participación de las mujeres en posiciones de liderazgo es una realidad en el escenario mundial. Sin embargo, un análisis de las posiciones de varias carreras muestra que este progreso ha sido insuficiente para conducir de manera equitativa el ascenso profesional de las mujeres en los más altos niveles de responsabilidad, poder y prestigio. En Brasil la situación no es diferente. Varios factores contribuyen a este fenómeno. Las influencias sociales y culturales desempeñan un papel particularmente importante en el desarrollo del talento para el liderazgo femenino: afectando no solo los patrones de comportamiento incorporados y mostrados por las mujeres, sino también la estructura de sus campos profesionales. Por lo tanto, este estudio tuvo como objetivo analizar el desarrollo del talento a la luz de los estudios de género, con énfasis en los factores que interfieren en el ascenso de las mujeres brasileñas hacia posiciones de poder y liderazgo. Con este enfoque se espera provocar una reflexión sobre cómo se perpetúan las condiciones de desigualdad que

* Renata Muniz Prado, Denise Souza Fleith, Both at the University of Brasilia.

Main contact Renata Muniz Prado Basto, e-mail address: pradobasto@gmail.com

Cómo citar este artículo: Prado, R. M. \& Fleith, D. S. (2018). Female Leadership Talent Development: The Brazilian Context. Avances en Psicología Latinoamericana, 36(2), 363-372. DOI: http://dx.doi.org/10.12804/revistas.urosario.edu.co/apl/a.4619 
sufren las mujeres y a menudo perpetúan y naturalizan mediante la valoración de su "diferencia".

Palabras clave: liderazgo, género, talento, mujeres brasileñas, subrepresentación femenina.

\section{Resumo}

A ascendente participação feminina em postos de liderança é uma realidade no cenário mundial. Contudo, ao se analisar o topo de diversas carreiras, verifica-se que o avanço ocorrido ainda não foi suficiente para impulsionar, de forma equânime, o crescimento profissional das mulheres a níveis hierárquicos de maior responsabilidade, poder e prestígio. No Brasil, essa realidade não é diferente. Diversos fatores contribuem para esse fenômeno, destacando-se as influências sociais e culturais no desenvolvimento do talento de liderança feminina, impactando não apenas os padrões de comportamentos incorporados e desempenhados pela mulher, mas também a estrutura do campo em que está inserida. Portanto, o objetivo deste estudo foi analisar o desenvolvimento do talento à luz dos estudos de gênero, com ênfase nos fatores que interferem na trajetória da mulher brasileira em direção à postos de poder e liderança. Espera-se que a compreensão desse fenômeno por essa perspectiva possibilite uma reflexão acerca da perpetuação da condição de desigualdade vivenciada pela mulher e que muitas vezes é naturalizada pela valorização da sua "diferença".

Palavras-chave: liderança, gênero, talento, mulher brasileira, sub-representação feminina.

\section{Introduction}

Women participation in leadership positions is increasing all over the world. Nevertheless, upon analyzing the top levels of several careers one can see that this progress has been insufficient to equitably drive the professional rise of women to the highest levels of responsibility, power and prestige (Eagly \& Chin, 2010; Fitzsimmons \&
Callan, 2015; Hoyt \& Murphy, 2015; Mundim, 2015; Nogueira, 2006).

In 2000, upon examining the world's biggest problems, the United Nations (UN) established eight Millennium Development Goals (MDGs) to be achieved by 2015, the third of which is to promote gender equality and empower women. To achieve them, the UN advocated for equity both in the labor market and in political representation, power and decision-making structures (ONU Mulheres, 2012).

The World Economic Forum (WEF) recently launched its global index on gender-based disparities, which builds upon a comparative study between countries that examine economic participation and opportunity, political empowerment, education and health. Brazil's scores dropped in nine of its subindexes. According to the study, while men and women have reached parity in health and education, the limited number of Brazilian women in formal politics and the slow ascension in female leadership in the labor force are the main causes for Brazil's regression. "Achieving gender equality is obviously necessary for economic reasons. Only those economies who have full access to all their talent will remain competitive and will prosper," noted Klaus Schwab, the World Economic Forum's founder and executive chairman (WEF, 2014, p. v).

Starting in the 1970's, backed by feminist movements, studies have been identifying constraints in the women leadership process and proposing strategies to overcome them. Since then much has been achieved. Today Brazilian women rank high in educational attainment and life expectancy, in addition to representing a significant share of the country's economically active population. However, women still receive lower wages, have less opportunities for professional advancement, and assume the bulk of household tasks and family care responsibilities (Biasoli-Alves, 2000; IBGE, 2014; SPM, 2015). This disparity indicates that women face greater difficulties than men in the course of their professional development. 
For Rocha-Coutinho and Coutinho (2011), the world of work is structured according to male standards, which explains the difficulties women face in being promoted and occupying more powerful positions in their fields. A change in beliefs and values is called for, with new conceptions of leadership and talent development that cover and include characteristics and needs that reflect the condition and reality of being a woman in the job market.

Several researches have also called attention to the underrepresentation of women in private and public power structures and to the difficulties women encounter in developing and expressing their potential. This phenomenon reflects several factors, particularly the social and cultural aspects that influence the development of female leadership talent, whose impacts extend beyond the behavioral patterns incorporated and displayed by women, permeating the very structure of their professional fields (Ayman \& Korabik, 2010; Cheung \& Halpern, 2010; Ely, Ibarra \& Kolb, 2011; Zauli, Torres \& Galinkin, 2012).

Gender is a contemporary and crosscutting subject that intrigues researchers of areas beyond economic, politics and education. We are clearly amidst a period of change brought on by globalization and technological development that has transformed the dynamics and structures of different social spheres, including family and the world of work. As such, psychological science plays a fundamental role in identifying and understanding gender in its new context, but also in designing strategies to ensure that the challenges of this transition do not prevent women from achieving their full potential (Alencar, 2015; Antunes \& Almeida, 2008; Noble, Subotnik \& Arnold, 1999; Zanello $\&$ Andrade, 2014).

The above referred studies point to some of the main barriers to the development of female potential and talent. According to Noble et al. (1999), gender stereotypes and expectations about women's roles deter or even prevent many women from achieving positions of notoriety or making significant contributions in different fields.

In view of the above, this article aimed to analyze the development of talent in the light of gender studies, emphasizing factors that hinder the rise of Brazilian women towards positions of power and leadership. We begin by addressing factors associated with gender inequality that constitute barriers for the women toward leadership roles, then, we provide an overview of the current cultural context of Brazilian women, and a review of studies on female leadership in the national context. We conclude by proposing some implications for future studies as well as possible measures to promote equity. Through this gender approach to the development of leadership talent we hope to foster a reflection on how the unequal conditions experienced by Brazilian women are perpetuated and often made to seem natural by valuing their "difference."

\section{Factors Associated with Gender Inequality}

Gender inequality in top management positions is often related to stereotypes that affect the construction of female subjectivity, blocking women and barring them from developing and expressing their skills and potential. Charyton, Elliott, Rahman, Woodard and Dedios (2011) conducted a comparative study of men and women awarded the Nobel Prize in Physics, Chemistry and Medicine from 1901 to 2006. Their findings indicate that although women do not differ from men in terms of competence and ability, they face greater environmental constraints that lead them to publish less and to be underrepresented in their areas of action.

Even actions to promote women's emancipation or empowerment display traces of the value assigned to traits and behaviors that encourage them to remain in unequal conditions. One example is 
to naturalize the "difference" between men and women by attributing idealized gender-specific skills and behaviors to women that were socially construed since childhood, including intrinsic aspects like sensitivity, frailness and feminine passivity.

According to Lagarde (2011), rather than being innate or determined by the biological nature of the female sex, the feminine condition is the result of a historical and social process. The way women are raised favors this antagonistic relationship between men and women. The author emphasizes that being a woman is not the opposite of being a man, and that by analyzing the power structures of society one can foster a critical reflection and achieve cultural change. Women's subordinate position is seen in all social classes and in the various dimensions of their lives (e.g., professional, familial, educational, political). Women in the $21^{\text {st }}$ century continue facing wage disparities, underrepresentation in top management positions, and existential conflicts in reconciling their careers and their personal lives.

A study conducted by Cheung and Halpern (2010) with women in top positions showed that these leaders had developed unique and successful ways of reconciling their professional duties with their family care responsibilities, which the authors referred to as being dually successful. A flexible work structure and the existence of a support network were the main factors that enabled their success in both spheres. In view of their findings, the researchers proposed a leadership model based on three factors: relationship-oriented leadership traits, team work and consensus-building, and an effective interface between family care and professional responsibilities.

Butler (1988) presents a conception of gender that cannot be ignored when discussing the differences associated to power relations. The author defines gender as a performance and states that dominant social and cultural processes must be deconstructed through conscious and subversive acts.
Gender is not passively scripted on the body, and neither is it determined by nature, language, the symbolic, or the overwhelming history of patriarchy. Gender is what is put on, invariably, under constraint, daily and incessantly, with anxiety and pleasure, but if this continuous act is mistaken for a natural or linguistic given, power is relinquished to expand the cultural field bodily through subversive performances of various kinds. (Butler, 1988, p. 531)

Women's entry into the work force in the postwar period, for instance, destabilized the patriarchal societal model in place at the time. On the other hand, it is important to note that "societies could never have lived, reproduced or developed without the household work of women, which is invisible" (Perrot, 2012, p. 109).

Butler (1988), Lagarde (2011) and Perrot (2012) agree that for a very long time women's empowerment took place in private quarters, marriage being a condition for their economic survival and motherhood for their femininity. Having to choose between staying at home or leaving to embrace a professional career gave rise to an existential conflict, since women have long been indoctrinated to believe they were born for motherhood, love and relationships. The authors suggest that giving visibility to the history of women as active subjects of their emancipation and offering other models of female empowerment, like women occupying positions of leadership and power previously held by men, may help to reduce such conflicts.

For Ayman and Korabik (2010), leadership behaviors are neither universal nor neutral. Culture and gender affect the leadership styles that people identify with, styles that often carry implicit stereotypes like traditional gender roles. Knowing the culture is essential to understand female leadership talent. In a desk study about creativity in different cultures, Lubart (2007) noted that opportunities given to men and women to express their creativity may differ from one domain to another. 
Despite the existence of internal factors, the external barriers chief among the reasons that explain difficulties women face in reaching leadership positions. Gender relations, distance from privilege, lack of opportunities, and stereotype threat are major delimiting factors on female achievement. They affect not only women expectation of themselves and their potential for flourishing, but the promotion of social outcomes as well.

\section{Brief Overview of the Current Cultural Context of Brazilian Women}

Brazil has the fifth biggest population and the seventh largest economy in the world. Women represent more than $51 \%$ of the Brazilian population. In fact, according to the annual socioeconomic report on women issued by the Brazilian Special Secretariat of Policies for Women (SPM, 2015), the older the age range the higher the proportion of women, which indicates a feminization of the elderly population. In addition, the total fertility rate is falling to levels below the replacement rate.

In 2012, women were responsible for $38 \%$ of Brazilian households, $42.7 \%$ of which were single parent families with children but no spouse. Only $3.5 \%$ of households with men as household heads were single parent families IBGE, 2014. Women's economic autonomy is linked to their insertion in the labor market, as is the equitable distribution of family care responsibilities. This data indicate that gender-oriented division of labor overburdens Brazilian women with an unfair share of household tasks, which constitutes an important challenge they must overcome if they are to continue working and rising in their professions.

Regarding access to education, women prevail in all levels. Nevertheless, indicators on the provision of training and research grants by the National Council for Scientific and Technological Development (CNPq) reveal that the more qualified the group, the less women it includes. This shows that the participation of women in academic and scientific activities has not occurred at the same rate as their growing insertion in the academic universe (Prado \& Fleith, 2012).

In the last decade the Brazilian government fostered significant progress towards gender equity and women's empowerment. Among other measures, it created the Ministerial Department of Policies for Women SPM, 2015 in 2003 and has since organized state and national conferences to prepare the National Plan of Policies for Women. In addition, in 2010 the country elected its first female president.

According to the National Monitoring Report on the eight Millennium Development Goals (MDGs) coordinated by the Institute of Applied Economic Research (IPEA) and the Secretariat of Planning and Strategic Investment of the Ministry of Planning, Budget and Management (SPI/MP), neither the educational attainment of Brazilian women nor the election of the first woman president in 2010 were able to significantly increase gender equity in power structures. This holds true as much in the workplace as in political representation in the executive, legislative, and judiciary branches of government (IPEA-SPI/MP, 2014).

Despite women's increased participation in this universe as a result of changes in their social and economic conditions, Brazil still faces one of the worst levels of female representation in the legislative and executive powers, ranking $131^{\text {st }}$ out of a total 152 countries (Inter-Parliamentary Union, 2014). Parity between men and women in the formal political system is essential not just for democracy or to ensure a proportional participation of all social segments, but also for the development of social wellbeing. Scholars of the area suggest this can partly be explained by traditional gender roles, sexual division of labor, and the political ideology and structure. They advocate that women have unique developmental patterns concerning their accomplishment that is usually influenced 
by gender bias (Glass \& Cook, 2016; Oliveira, 2012; Parra Alfonso, Domínguez Blanco \& Cortés Ramírez, 2008; Reis, 1998; Rimm, 2006).

Clearly, many challenges remain in promoting gender equity and the empowerment of Brazilian women. Studies emphasize that gender inequality persists despite the progress made, especially in top leadership positions. This in turn highlights the need to increase our understanding of how leadership talent develops among women in various contexts.

\section{Considerations on Female Leadership Talent in Brazil}

Whether or not latent talent is able to emerge and be recognized is determined by aspects that also lie outside the individual, like characteristics of the environment, culture or moment in history. One example is what happens with women, where cultural elements like values and beliefs maintain or reinforce sexual stereotypes that constitute external and internal barriers for women, like less opportunities for professional advancement or limited faith in their own potential.

A Brazilian study evaluated the scientific production on female leadership, using the words leadership and woman, without a period delimitation. Results pointed the increase of publication on the topic, which indicates a growing interest in the theme. Also it suggested that understanding female leadership requires a different approach than understanding male leadership, highlighting the different processes that men and women go through to achieve positions of power. It also emphasizes the need to study the female leadership construct in the various contexts in which it occurs, like communal, religious, scientific, sports, organizational and political ones (Mundim, Wechsler \& Nakano, 2013).

Mourão and Galinkin (2008) researched on the social representations of female management. They enrolled 74 women and 72 men and divided them into teams led by women that occupied top management positions in the federal government. The researchers found certain characteristics they attributed to the female way of managing, like emphasizing interpersonal relations, respecting people, showing concern for the quality of the team's work and fostering promotion and inclusion. They also noted that women seemed to transfer what they learned at home to the workplace.

A discussion on the female participation in politics was conducted by Abrão (2009) on a study of women running for municipal legislative positions. Five female candidates were interviewed in order to understand the development process of their political trajectories. The analysis demonstrates the presence of patriarchal principles, which reflect on internal barriers, or on the way they understand the division of gender roles and the characteristics of their political performance. The study underlines a female way of doing politics. Women were considered more sensitive, incorruptible and zealous, which might be called an affective model of political exercise. For women this belief might pose a risk, since stereotypes are often reinforced by associating maternal characteristics to professional roles, especially in environments where male traits are more valued.

To understand the influence of gender roles in women's political insertion, Ramos (2014) interviewed men and women of the middle and lower classes of the Federal District. The findings indicated that women's participation in politics is influenced by stereotypes associated to motherhood, and that feminine traits may hinder their rise in political careers.

A Brazilian survey of 111 prominent women in the academia and the sciences found that deterrents like gender stereotypes took precedence over promoters over the course of their careers. On the other hand, the main external factors that facilitated their high professional attainment were having role models at the start of their careers, an excellent education and family support. The 
survey also showed that women's participation tends to drop as the group becomes more qualified (Prado, 2010). Although extensive social progress has enabled a significant increase in women's participation in various professional contexts, much remains to be done to achieve gender equality.

\section{Final Considerations}

Academic researchers, government officials and legislators have emphasized the need to invest in developing the potential of adult women, steering them towards positions of increased power and leadership (IPEA-SPI/MP, 2014; Mundim, 2015; Prado \& Fleith, 2012; SPM, 2015). Discussions involve the impacts of wasting the talent of over half of the world's population on the global economy. Even greater than these influences on the economy, however, there are on the health, wellbeing and quality of life of talented women who want to dedicate themselves to their careers - and develop professionally - without having to give up other aspects of their lives.

Gender equity has been a constant pursuit of feminist movements in the most varied social spheres. The autonomy that comes from being free to make one's own choices should be a human rights principle, a condition for the full exercise of citizenship, and never determined by gender. In that sense, understanding and promoting women's empowerment should be a social principle.

When emphasizing the relevance of problems experienced by women when pursuing cultural and social change, one should not disregard the impact of social measures and policies. Nevertheless, despite exposing and discussing women's problems and unequal treatment and implementing many social interventions and affirmative actions, Brazil is yet to achieve a fair level of equal rights, especially in social roles of greater power and leadership.

People should be encouraged to value the responsibilities of adults instead of those of men or women. In addition, the social division of family care responsibilities should be supported through public policies. Fostering a new sexual division of labor will require men to participate more directly in household affairs while women become more involved in public affairs, favoring relations based on shared responsibility. Measures to achieve this include increasing the length of paid male paternity leave or introducing a shared family leave, incentivizing flexible work hours, and providing full-time daycare and schools as well as efficient public transportation. This would allow women to choose to be mothers without compromising their citizenship or autonomy.

Another possibility would be to increase women's visibility, giving them a chance to be heard outside their homes. In so doing we would also provide new representations of female leadership. Studies of women who rose to the top of their professions or occupied positions of social prestige previously held by men are a strategy used in the field of psychology to take the focus away from studies that emphasize how women's lives revolve around love and motherhood.

\section{References}

Abrão, L. G. M. (2009). A participação política da mulher: Uma análise do ponto de vista psicológico [The political participation of women: An analysis from the psychological point of view] (Unpublished doctoral dissertation). Universidade de Brasilia, Brasilia.

Alencar, E. M. L. S. (2015). Contribuições de estudos de caso para o avanço do conhecimento sobre superdotação [Contributions of case studies for the advancement of knowledge on giftedness]. Psicologia Escolar e Educacional, 19, 427-434. DOI: 10.1590/2175-3539/2015/0193830

Antunes, A. \& Almeida, L. S. (2008). Variáveis pessoais e contextuais da excelência no feminino: Um estudo de caso. [Personal and contextual 
variables of excellence in women: A case study]. Sobredotação, 9, 63-75.

Ayman, R. \& Korabik, K. (2010). Leadership: Why gender and culture matter. American Psychologist, 65, 157-170. DOI: 10.1037/a0018806

Biasoli-Alves, Z. M. M. (2000). Continuidades e rupturas no papel da mulher brasileira no século XX [Continuities and ruptures in the Brazilian women role in the $20^{\text {th }}$ century]. Psicologia: Teoria e Pesquisa, 16, 233-239. Retrieved from http:// www.scielo.br/pdf/\%0D/ptp/v16n3/4810.pdf

Butler, J. (1988). Performing acts and gender constitution: An essay in phenomenology and feminist theory. Theater Journal, 40, 519-531. Retrieved from http://www.jstor.org/stable/3207893?origin $=$ JSTOR-pdf

Charyton, C., Elliott, J. O., Rahman, M. A., Woodard, J. L. \& Dedios, S. (2011). Gender and science: Women Nobel laureates. The Journal of Creative Behavior, 45, 203-214. DOI: 10.1002/j.2162-6057.2011.tb01427.x

Cheung, F. M. \& Halpern, D. F. (2010). Women at the top: Powerful leaders define success as work+family in a culture of gender. American Psychologist, 65, 182-193. DOI: 10.1037/ a0017309

Eagly, A. H. \& Chin, J. L. (2010). Diversity and leadership in a changing world. American Psychologist, 65, 216-224. DOI: 10.1037/a0018957

Ely, R. J., Ibarra, H. \& Kolb (2011). Taking gender into account: Theory and design for women's leadership development programs. Academy of Management Learning \& Education, 10, 474493. DOI: $10.5465 /$ amle. 2010.0046

Fitzsimmons, T. W. \& Callan, V. J. (2015). Applying a capital perspective to explain continued gender inequality in the $\mathrm{C}$-suite. The Leadership Quarterly. Advance online publication. DOI: 10.1016/j.leaqua.2015.11.003

Glass, C. \& Cook, A. (2016). Leading at the top: Understanding women's challenges above the glass ceiling. The Leadership Quarterly, 27, 51-63. DOI: 10.1016/j.leaqua.2015.09.003
Hoyt, C. L. \& Murphy, S. E. (2015). Managing to clear the air: Stereotype threat women, and leadership, The Leadership Quarterly. Advance online publication. DOI: 10.1016/j.leaqua.2015.11.002

Instituto de Pesquisa Econômica Aplicada (IPEA), \& Ministério do Planejamento, Orçamento e Gestão - Secretaria de Planejamento e Investimentos Estratégicos (SPI/MP). (2014). Objetivos do desenvolvimento do milênio: Relatório Nacional de Acompanhamento. Brasília: IPEA/ SPI/MP. Retrieved from http://www.pnud.org. br/Docs/5_RelatorioNacionalAcompanhamentoODM.pdf

Instituto Brasileiro de Geografia e Estatística (IBGE). (2014). Sintese de indicadores sociais: Uma análise das condições de vida da população brasileira. [Social indicators summary: An analysis of the living conditions of the Brazilian population] Rio de Janeiro: IBGE. Retrieved from http://biblioteca.ibge.gov.br/ visualizacao/livros/liv91983.pdf

Inter-Parliamentary Union. (2014). Women in national parliaments. New York: IPU. Retrieved from http://www.ipu.org/wmn-e/arc/classif010814. htm

Lagarde, M. (2011). Los cativeiros de las mujeres madresposas, monjas, putas, presas y locas. Madrid: San Cristobal.

Lubart, T. (2007). Psicologia da criatividade [Psychology of creativity]. Porto Alegre: Artmed.

Mourão, T. F., \& Galinkin, A. L. (2008). Equipes gerenciadas por mulheres: Representações sociais sobre o gerenciamento feminino [Women managers' teams: Social representations about feminine management]. Psicologia: Reflexão e Crítica, 21, 91-99. DOI: 10.1590/S010279722008000100012

Mundim, M. C. B. (2015). Excelência criativa de mulheres brasileiras e portuguesas [Creative excellence of Brazilian and Portuguese women] (Unpublished doctoral dissertation). Pontifícia Universidade Católica de Campinas, Campinas. 
Mundim, M. C. B., Wechsler, S. \& Nakano, T. (2013). Liderança feminina: $\mathrm{O}$ estado da arte nas publicações [Female leadership: The state of art on Brazilian publication]. Revista Latino-Americana de Geografia e Gênero, 4, 55-65. DOI: 10.5212/Rlagg.v.4.i2.055065

Noble, K., Subotnik, R. \& Arnold, K. (1999). To thine own self be true: A new model of female talent development. Gifted Child Quarterly, 43, 140-149. DOI: 10.1177/001698629904300302

Nogueira, M. C. O. C. (2006). Os discursos das mulheres em posições de poder [The discourse of women in position of power]. Cadernos de Psicologia Social do Trabalho, 9, 57-72. DOI: 10.11606/issn.1981-0490.v9i2p57-72

Oliveira, L. S. O. (2012). Teto de vidro: Relações de gênero, relações de poder e empoderamento das mulheres na Polícia Militar [Glass ceiling: Gender relations, power relations and the empowerment of women in the military police] (Unpublished doctoral dissertation). Universidade Federal da Bahia, Salvador.

ONU Mulheres. (2012). O Futuro que as mulheres querem: Uma visão do desenvolvimento sustentável para todos [The future women want: A vision of sustainable development for all]. Rio de Janeiro: ONU Mulheres. Retrieved from http://onumulheres.org.br/wp-content/themes/ vibecom_onu/pdfs/futuro.pdf

Parra Alfonso, G. P., Domínguez Blanco, M. E. \& Cortés Ramírez, D. A. (2008). Participación social y política: Estudios de liderazgos femininos en Bogotá y Cundinamarca. International Journal of Psychological Research, 1, 40-48. Retrieved from http://www.redalyc.org/articulo. oa? id=299023503007

Perrot, M. (2012). Minha história das mulheres [My history of women]. São Paulo: Contexto.

Prado, R. M. (2010). O talento em uma perspectiva feminina: Características individuais e familiares de pesquisadoras de destaque [Talent in a female perspective: Individual and family characteristics of eminent researchers] (Unpublished thesis for master's degree). Universidade de Brasília, Brasilia

Prado, R. M. \& Fleith, D. S. (2012). Pesquisadoras brasileiras: Conciliando talento, ciência e família [Brazilian researchers: Combining talent, science and family]. Arquivos Brasileiros de Psicologia, 64, 19-34. Retrieved from http://pepsic. bvsalud.org/pdf/arbp/v64n2/v64n2a03.pdf

Ramos, D. P. (2014). Representações sobre gênero e política no Distrito Federal [Representations of gender and politics in the Brazilian Federal District] (Unpublished doctoral dissertation). Universidade de Brasília, Brasília.

Reis, S. M. (1998). Work left undone: Choices and compromises of talented females. Mansfield Center, CT: Creative Learning Press.

Rimm, S. (2006). Winning girls, winning women. In B. Wallace \& G. Eriksson (eds.), Diversity in gifted education: International perspectives on global issues (pp. 189-196). New York: Routledge.

Rocha-Coutinho, M. L. \& Coutinho, R. R. (2011). Mulheres brasileiras em posições de liderança: Novas perspectivas para antigos desafios. [Brazilian women in leadership positions: New perspectives for old challenges]. Economia Global e Gestão, 16, 61-79. Retrieved from http://www. scielo.mec.pt/pdf/egg/v16n1/v16n1a05.pdf

Secretaria de Políticas para as Mulheres (SPM). (2015). Relatório anual socioeconômico da mulher [Women socioeconomic annual report]. Brasilia: Secretaria de Políticas para as Mulheres. Retrieved from http://www.spm.gov. br/central-de-conteudos/publicacoes/publicacoes/2015/livro-raseam_completo.pdf

World Economic Forum (WEF). (2014). The Global Gender Gap Report 2014. Geneva: World Economic Forum. Retrieved from http://www3. weforum.org/docs/GGGR14/GGGR_CompleteReport_2014.pdf

Zanello, V. \& Andrade, A. P. M. (2014). Saúde mental e gênero: Diálogos, práticas e interdisciplinariedade [Mental health and gender: 
Dialogues, practice and interdisciplinarity]. Curitiba: Appris.

Zauli, A., Torres, C. V. \& Galinkin, A. L. (2012). Câmara dos deputados: Democracia e igualdade de oportunidade entre mulheres e homens?
[Chamber of deputies: Democracy and equality of opportunity between women and men]. Cadernos de Psicologia Social do Trabalho, 15, 4964. DOI:10.11606/issn.1981-0490.v15i1p49-64

Received: February 17, 2016

Accepted: June 24, 2017 